\title{
Natural Anti-Estrogen Receptor Alpha Antibodies Able to Induce Estrogenic Responses in Breast Cancer Cells: Hypotheses Concerning Their Mechanisms of Action and Emergence ${ }^{t}$
}

\author{
Guy Leclercq \\ Laboratoire de Cancérologie Mammaire, Institut J. Bordet, Centre des Tumeurs de l'Université Libre de Bruxelles, 1, \\ rue Héger-Bordet, 1000 Brussels, Belgium; guy.leclercq@ulb.ac.be \\ + This paper may be considered as a tribute to my colleague Albert Borkowski, Internist and Director of the \\ Endocrinology Laboratory of the Institute J. Bordet, who passed away in 2007 and who first described certain \\ biological functions of these antibodies.
}

Received: 25 December 2017; Accepted: 25 January 2018; Published: 30 January 2018

\begin{abstract}
The detection of human anti-estrogen receptor $\alpha$ antibodies (ER $\alpha \mathrm{ABs})$ inducing estrogenic responses in MCF-7 mammary tumor cells suggests their implication in breast cancer emergence and/or evolution. A recent report revealing a correlation between the titer of such antibodies in sera from patients suffering from this disease and the percentage of proliferative cells in samples taken from their tumors supports this concept. Complementary evidence of the ability of ER $\alpha A B$ s to interact with an epitope localized within the estradiol-binding core of ER $\alpha$ also argues in its favor. This epitope is indeed inserted in a regulatory platform implicated in ER $\alpha$-initiated signal transduction pathways and transcriptions. According to some experimental observations, two auto-immune reactions may already be advocated to explain the emergence of ER $\alpha$ ABs: one involving probably the idiotypic network to produce antibodies acting as estrogenic secretions and the other based on antibodies able to abrogate the action of a natural ER $\alpha$ inhibitor or to prevent the competitive inhibitory potency of released receptor degradation products able to entrap circulating estrogens and co-activators. All of this information, the aspect of which is mainly fundamental, may open new ways in the current tendency to combine immunological and endocrine approaches for the management of breast cancer.
\end{abstract}

Keywords: estrogen receptor $\alpha$; natural antibodies; estrogenic responses; mechanism of action; auto-immune diseases

\section{Introduction}

Among modulators of steroid hormone receptors, natural anti-estrogen receptor antibodies (ERABs) are of peculiar interest in view of their implication in the emergence and/or evolution of autoimmune diseases and cancers [1]. The present paper focuses on the potential biological relevance of these antibodies in the context of the hormone-dependence of breast cancer, a topic on which I have been working for more than four decades.

The recent finding by the group of Pierdominici and Ortona of a correlation between the titer of ERABs raised against the alpha form of the receptor (ER $\alpha A B s)$ in sera from a series of women with breast cancer and the percentage of Ki67-positive cells (a known marker of proliferation) in samples taken from their tumors [2] offered to me an opportunity to discuss here the possible implication of these antibodies in the development of breast cancers. In fact, this concept had already been proposed in the late 1980s by my colleague Borkowski, who detected a sub-population of IgGs able to interact with the estradiol $\left(E_{2}\right)$ binding site of $E R \alpha$ in sera from healthy women [3,4]. This work, in which I collaborated, revealed moreover the ability of these IgGs to induce estrogenic (or estrogenic-like) 
responses in ER $\alpha$-positive MCF-7 breast cancer cells, suggesting that they act on these cells as the hormone [4]. Further studies revealed that this view was only partly true: the major estrogenic activity of the IgGs seemed to derive from the neutralization of ER $\alpha$-related peptides able to inhibit its activation [5]. Skepticism concerning the biological significance of these various observations, as well as their potential insertion in therapeutic programs forced us to stop our investigations. We hope that the recent investigations of Pierdominici and Ortona, which also concern the prominent role of estrogens in autoimmune diseases [6], may encourage the scientific community to assess again questions relevant to the suspected role of such natural anti-ER $\alpha$ antibodies in breast cancer.

The present paper devoted to this hope mainly concerns the mechanism(s) by which ER $\alpha$ ABs may operate; processes implicated in their emergence will be also evoked. Available data being quite tenuous, my proposals are largely speculative. Nevertheless, I anticipate that they may open avenues for new experimentations not necessarily restricted to $\mathrm{ER} \alpha$, since the existence of natural antibodies raised against other steroids hormone receptors has been reported, as will be recalled briefly in the next section.

\section{Natural Antibodies against Steroid Hormone Receptors, the Existence of Which Had Been Reported about Three Decades Ago}

To my knowledge, the first evocation of such antibodies must be attributed to the group of O'Malley that reported in 1981 the existence of "spontaneous" antibodies raised against the progesterone receptor in two thirds of sheep sera [7]. Surprisingly, these authors limited their investigation to the assessment of the binding properties of these antibodies for the $\alpha$ and $\beta$ isoforms of this receptor without raising any questions relevant to their biological role. This topic was addressed in the following year by Liao and Witte who reported a high titer of anti-androgen receptors in patients with prostate disease, when compared with normal subjects [8]. These authors logically proposed some relevance to this detection in terms of disease management. The discovery of the existence of anti-ER $\alpha$ may be ascribed to Borkowski [3], as well as to Muddaris and Peck Jr. [9], who detected them at the same time. While Borkowski focused his studies on the biological function of these antibodies, Muddaris and Peck reported striking sex and age-related differences in the level of the latter: young females displayed a higher titer than corresponding males. This level also declined in middle age, before increasing in old age, in contrast to males in which it continuously decreased. Although these various observations were quite provocative, they failed to generate a significant interest for about two decades, as previously mentioned.

\section{Major Properties of ER $\alpha$ ABs}

\subsection{Ability to Induce Estrogenic (or Estrogenic-Like) Responses}

As reported below, ER $\alpha \mathrm{ABs}$ act as ER $\alpha$ agonists through both non-genomic and genomic procedures, which operate sequentially, the non-genomic preceding largely the genomic procedures [10,11]. This suspected co-operative mechanism [11-14], detected with MCF-7 breast cancer cells, seems to be initiated at the plasma membrane (Section 3.2).

\subsubsection{Signal Transduction Activation and Subsequent Cell Proliferation Enhancement}

Highly purified ER $\alpha$ ABs almost immediately activate the phosphorylation of ERK (Extracellular regulated kinase) in MCF-7 cells without producing any similar effect on Akt (Protein kinase B) [2]. The maximal effect of the antibodies occurs after $5 \mathrm{~min}$ and subsequently declines, returning to the original level after $30 \mathrm{~min}$. As expected, a significant increase in proliferation is recorded after one day of treatment. 


\subsubsection{Transcriptions and Related ER $\alpha$ Level Changes}

Over-night exposure of MCF-7 cells to highly purified ER $\alpha$ ABs (IgGs) enhances their level of progesterone receptors in a dose-dependent manner, as observed with $\mathrm{E}_{2}$ used as the control; this increase is progressively inhibited by pure antiestrogens $[4,5]$. The same behavior is recorded for cathepsin D secretion. A loss of the capacity of the cells to specifically incorporate $\left[{ }^{3} \mathrm{H}\right] \mathrm{E}_{2}(\mathrm{ER} \alpha$ whole cell assay) occurs in parallel, which may be ascribed to a decrease of the ER $\alpha$ level, detected by Western blotting. IgGs also partially abrogate the capacity of the cells to incorporate $\left.{ }^{3} \mathrm{H}\right] \mathrm{E}_{2}$ in the presence of an analog of hydroxy-tamoxifen, which stabilizes the receptor within the nucleus [15], as does $\mathrm{E}_{2}$.

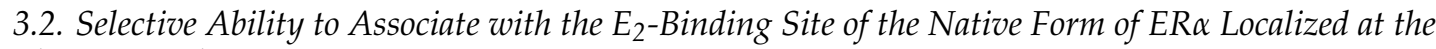 Plasma Membrane}

When submitted to low-salt sucrose gradient sedimentations, ER $\alpha$ from cytosolic extracts is known to migrate within two distinct oligomeric structures, i.e., of 4 and $8 S$ (note that these velocities may slightly differ according to the nature of the tissues from which ER $\alpha$ is extracted, the experimental conditions, as well as the choice of the sedimentation markers used for their assessment) $[16,17]$. The $4 \mathrm{~S}$ entity contains proteolytic products of the receptor, while the latter is maintained within the $8 \mathrm{~S}$ entity in its native form $(67 \mathrm{kDa})$ by a protective action of chaperones with which it associates. Interactions between highly purified $\mathrm{ER} \alpha \mathrm{ABs}$ (IgGs) and $\mathrm{ER} \alpha$ occur in the region of its $\mathrm{E}_{2}$-binding site since an increase of sedimentation velocity of the $8 \mathrm{~S}$ oligomer is detected when the $\left[{ }^{3} \mathrm{H}\right] \mathrm{E}_{2}$ labeling of the receptor is performed after sedimentation on the fractions collected from the gradient. With pre-labeled cytosols, this sedimentation shift is replaced by a partial displacement of bound $\left[{ }^{3} \mathrm{H}\right] \mathrm{E}_{2}$ by the IgGs [3]. Complementary experiments including an assessment of the binding parameters of $\left[{ }^{3} \mathrm{H}\right] \mathrm{E}_{2}$ to $\mathrm{ER} \alpha$, in the absence and the presence of increasing amounts of these IgGs, respectively, confirmed the implication of the $E_{2}$ binding site of the receptor in this complex. Accordingly, these IgGs behaved as competitive inhibitors (increase of $K_{d}$ values) [3], a finding in agreement with the recent identification of an epitope able to recognize ER $\alpha \mathrm{ABs}\left(\mathrm{Y}^{459} \mathrm{TFLSSTLKSLEE}^{471}\right.$; Figure 1) within the $\mathrm{E}_{2}$-binding core of ER $\alpha$ (Asn309-Lys529; MW: $26 \mathrm{kDa}$ [18]) [2].

Interestingly, this Tyr459-Glu471 epitope contains a small motif (Thr465-Ser468), which is cleaved under proteolytic attack without any loss of $\mathrm{E}_{2}$ binding ability [18], a property resulting from a cutting of the estrogen-binding core of ER $\alpha$ in two distinct entities $(7$ and $17 \mathrm{kDa})$ that stick together through hydrophobic contacts [19]. According to our sedimentation data, such a complex would logically be sufficient for ER $\alpha \mathrm{ABs}$ recruitment by the "pseudo" native ER $\alpha$ when it is stabilized in a peculiar oligomeric quaternary structure. Hence, one may understand that the known dissociation of such a structure at the time of ER $\alpha$ activation under the action of an appropriate modulator affects the topology of the $\mathrm{ER} \alpha$-binding core, giving rise therefore to a loss of its recruitment potency for ER $\alpha \mathrm{ABs}$, a property that manifestly does not hold for $\mathrm{E}_{2}$ and most probably other conventional estrogenic ligands [20-23].

This suspected binding selectivity, as well as the large size of ER $\alpha A B s$ may explain their association in living cells with the plasma membrane-bound receptor form $(\mathrm{mER} \alpha)$ [2], principally localized within caveolae [10,11]. This peculiar localization, which results, at least in part, from the palmitoylation of the native (newly-synthetized) receptor [13], appears especially appropriate for this association contributing to rapid, non-genomic, responses (in the present context, ERK phosphorylation; Section 3.1.1). It does not indeed imply any navigation of ER $\alpha A B s$ across the plasma membrane to reach oligomeric complexes in which they would moreover not easily internalize to interact with the native and non-markedly altered receptor forms. 
Non-genomic function

Membrane-bound and cytoplasmic processes

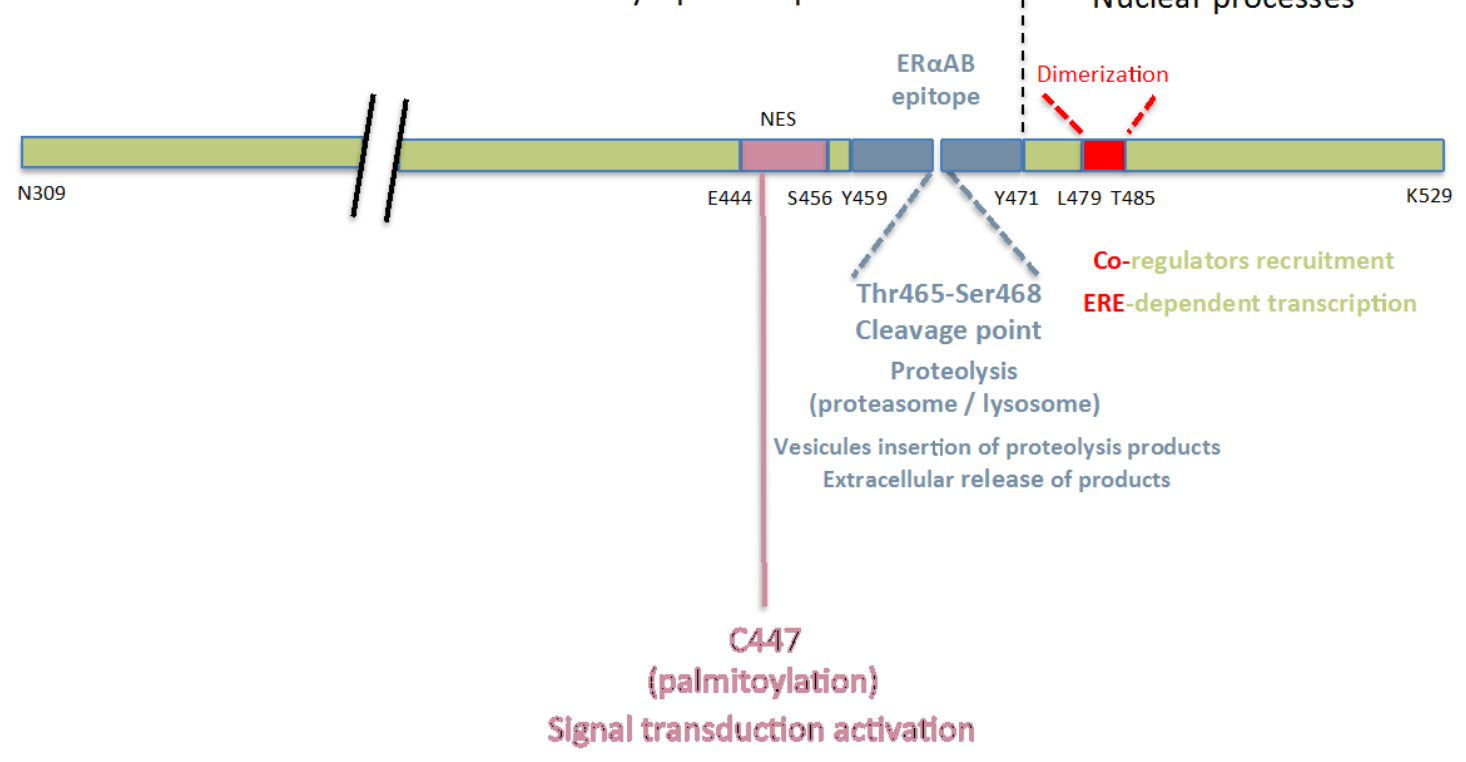

\section{Genomic function}

Nuclear processes

Dimerization

529

Figure 1. Schematic representation of the regulatory platform of the $E_{2}$-binding core of ER $\alpha$ (N309-K529), postulated to mainly contribute to the onset of non-genomic and genomic responses induced by $E_{2}$ and $E R \alpha A B s$. The ER $\alpha A_{B B s}$ epitope (Y459-E471) occupies a central, pivotal position localized between two motifs, each of them being implicated in one of these two types of responses (non-genomic, E444-S456; genomic, L479-T485). Functions of these three amino-acids sequences, as well as biological consequences resulting from $\mathrm{E}_{2} / \mathrm{ER} \alpha \mathrm{ABs}$ binding and consecutive activation of related inter-relationships between motifs of the platform are defined below (for details, see Section 3.3).

\subsection{Potent Regulatory Functions of the ER $\alpha A B$-Binding Epitope}

The sensitivity to proteolytic attacks of the Thr464-Ser468 amino acid sequence of the ER $\alpha$ AB-binding epitope of ER $\alpha$ suggests its inclusion within a surface-exposed region, a property usually recorded with "regulatory platforms" subjected to recruitment and exchange of co-regulators [24]. The identification within this epitope of two functional motifs localized respectively on the left and right sides of the $\mathrm{ER} \alpha \mathrm{AB}$-binding epitope supports such a view.

The left-side sequence ( $\mathrm{H}^{444} \mathrm{FVCLKSIILLNS}{ }^{456}$; Figure 1) corresponds indeed to an identified nuclear exclusion signal that contributes to the return of the activated ER $\alpha$ within the cytoplasm, where it is subjected to proteasomal degradation [24-27]. This step is key for the pursuit of previously initiated transcriptional processes. Hence, this motif would play a role in ER $\alpha$ intracellular trafficking as well as in its resulting turnover rate and related biological activity $[11,13,24]$. The presence within this motif of Cys-447, the palmitoylation of which favors the anchorage of the receptor with the plasma membrane, validates this proposal [28]. In contrast, the right-side motif ( $\mathrm{L}^{479} \mathrm{DKTITDT}^{485}$ ) seems mainly to contribute to (Estrogen response element) ERE-dependent transcription since it corresponds to one of the three amino-acids sequences of the ER $\alpha$ homo-dimerization interface required for such transcription [29].

Hence, the pivotal position of the Thr465-Ser468 sequence within the $E_{2}$-binding core of ER $\alpha$ (which contains the ER $\alpha \mathrm{ABs}$ binding epitope) confers to this sequence a primordial role in the onset of quasi-immediate non-genomic responses, as well as subsequent genomic responses. Such a dual capacity of action is reminiscent of a model proposed to explain how a ligand of the so-called nuclear receptor family may activate rapid signal transduction pathways issued from the cellular membrane, as well as genes' expression, either individually or sequentially [30,31]. 
According to this model, all ligands' binding sites of the nuclear receptor family are composed of two adjacent cavities in which potent agonists and antagonists may penetrate [30,31]; for ER $\alpha$ and $\beta$, see [32]. One of these cavities corresponds to a channel conducting to the other cavity in which selected ligands may be engulfed; the capacity of the ligands to open a protective barrier localized at the entrance of this second cavity might regulate this selection. Molecular interactions between receptors, chaperones and co-regulators are also implicated in this access-regulatory process. The entrance channel, in which access is less restrictive, is directly implicated in quasi-immediate activation of signal transduction pathways, while the cavity in which ligands are engulfed corresponds to the pocket contributing to receptor-mediated transcription, the topology of which has been established by X-ray diffraction crystallography. Cellular localization of the receptor is logically a complementary factor involved in this dual regulation.

Logically, the rapid ER $\alpha \mathrm{AB}$-induced ERK phosphorylation implicated in the enhancement of MCF-7 cells' proliferation (Section 3.1.1) may derive from a relatively low specific interaction of these antibodies with the entrance cavity, the structure of which may be related to the left-side motif implicated in non-genomic responses. Such a hypothesis may also hold to some extent for subsequent indirect induction of ERE-dependent transcription, since this left-side motif seems to play a role in the intracellular trafficking of the receptor, which regulates such transcription. ER $\alpha A B-m e d i a t e d$ enhancement of the progesterone receptor level may obviously not result from an engulfment of these antibodies within the putative adjacent cavity implicated in gene expression. Access to this adjacent cavity being under the control of a barrier, one may propose that interactions between ER $\alpha \mathrm{ABs}$ and specific residues of the entrance cavity in which they may penetrate would suppress the repressive function of the barrier, favoring thereby ER $\alpha$-mediated transcriptions. Receptor-related binding motifs of the plasma membrane may contribute to this property.

\section{ER $\alpha$-Related Sites Potentially Able to Contribute to the Mechanism of Action of ER $\alpha$ ABs}

Several sites identified on the plasma membrane may legitimately be proposed as potential alternative targets for ER $\alpha \mathrm{AB}$-induced responses, some of them acting cooperatively with mERs [33]. Some of these sites are devoid of any $E_{2}$-binding ability (i.e., HER2, EGFR), while others attract the hormone as demonstrated with synthetized $E_{2}$-conjugates unable to penetrate the cells [34]. Among such $E_{2}$-binding targets, two splice receptor variants (ER $\alpha 36$ and ER $\alpha 46$; see $[35,36]$ and the references therein), as well as a G protein-coupled receptor (GPR30 [37-39]) have been especially well studied. The capacity of GPR30 to interact with calmodulin, as well as with the calmodulin-binding site of $E R \alpha$, implicating its dimerization for the enhancement of ERE-dependent transcription [40-43], would confer to this peculiar receptor a potent role in ER $\alpha \mathrm{AB}$-induced genomic functions. In fact, the capacity of GPR30 to move between the plasma membrane, the endoplasmic reticulum and the nucleus advocates in favor of its contribution to other ER $\alpha$-mediated processes under the control of the antibodies [37,44]: GPR30 appears indeed to be an actor involved in the intracellular trafficking of the receptor governing its various biological functions.

Of course, the implication of such receptor-related sites in the onset of ER $\alpha \mathrm{AB}$-induced responses needs to be validated or rejected. Measurement of markers $\left(\mathrm{Ca}^{2+}\right.$ fluxes or secondary messengers such as c-AMP or IP3) may be helpful in this regard, especially for the evaluation of complementary $\mathrm{ER} \alpha$-independent processes [33]. In this context, specific antagonists with a special emphasis on compounds abrogating the action of HER2, EGFR or GPR30 need also to be tested. This approach being at the present time quite marginal $[2,5]$, one may consider that any use of such antagonists in the clinical perspective is out of scope, even if humanized versions of monoclonal antibodies raised against HER2 (trastuzumab, pertuzumab) seem appropriate for a first-line experimental assessment $[45,46]$. Induction by such drugs of a decrease of efficiency of signal transductions initiated by the putative action of ER $\alpha$ ABs at the level of HER2 might alter growth of breast cancer cells, which in connection with the known antibody-dependent cellular cytotoxicity (ADCC) of these compounds related to their ability to recruit and activate natural killer cells (NK) would generate a major curative effect, even 
in the absence of ER $\alpha$. Note in this context that pertuzumab abrogates the hetero-dimerization of HER2 with other members of the HER family, while trastuzumab mainly affects its homo-dimerization. Since such dimerizations are implicated in the activation of signal transductions enhancing cell growth, one may consider that pertuzumab might be more efficient for blocking a putative ER $\alpha \mathrm{ABs}$ association with membrane ER $\alpha$-related receptors, promoting proliferation.

Finally, it should be stressed that the estrogen activity of ER $\alpha$ ABs should not necessarily be derived from a direct interaction with the plasma membrane-bound $\mathrm{E}_{2}$-binding site. This assumption results from experiments conducted with anti- $\mathrm{E}_{2} \sim \mathrm{BSA}$ antibodies and highly purified $\mathrm{ER} \alpha \mathrm{BAs}$ (IgGs), which displayed an estrogenic activity [5]. Anti- $\mathrm{E}_{2} \sim \mathrm{BSA}$ antibodies sharing most likely some structural similarities with the hormone binding site of $E R \alpha$, the authors of this observation concluded that these two classes of antibodies may act as "soluble ER $\alpha$ forms" present in the blood to liberate, by a competitive process, the receptor from the repressive action exerted by a peptide inhibitor looking structurally like $\mathrm{E}_{2} \sim \mathrm{BSA}$. Hence, the estrogenic activity of a subpopulation of $\mathrm{ER} \alpha \mathrm{ABs}$ may result, at least in part, from the ability to abrogate the effect of ER $\alpha$ co-repressors. If confirmed, this concept would logically also hold for other possible ER $\alpha$ ABs targets, as described below.

All hypotheses evoked in Sections 3 and 4 to explain the mechanisms by which ER $\alpha$ ABs may generate estrogenic responses are schematically summarized in Figure 2.

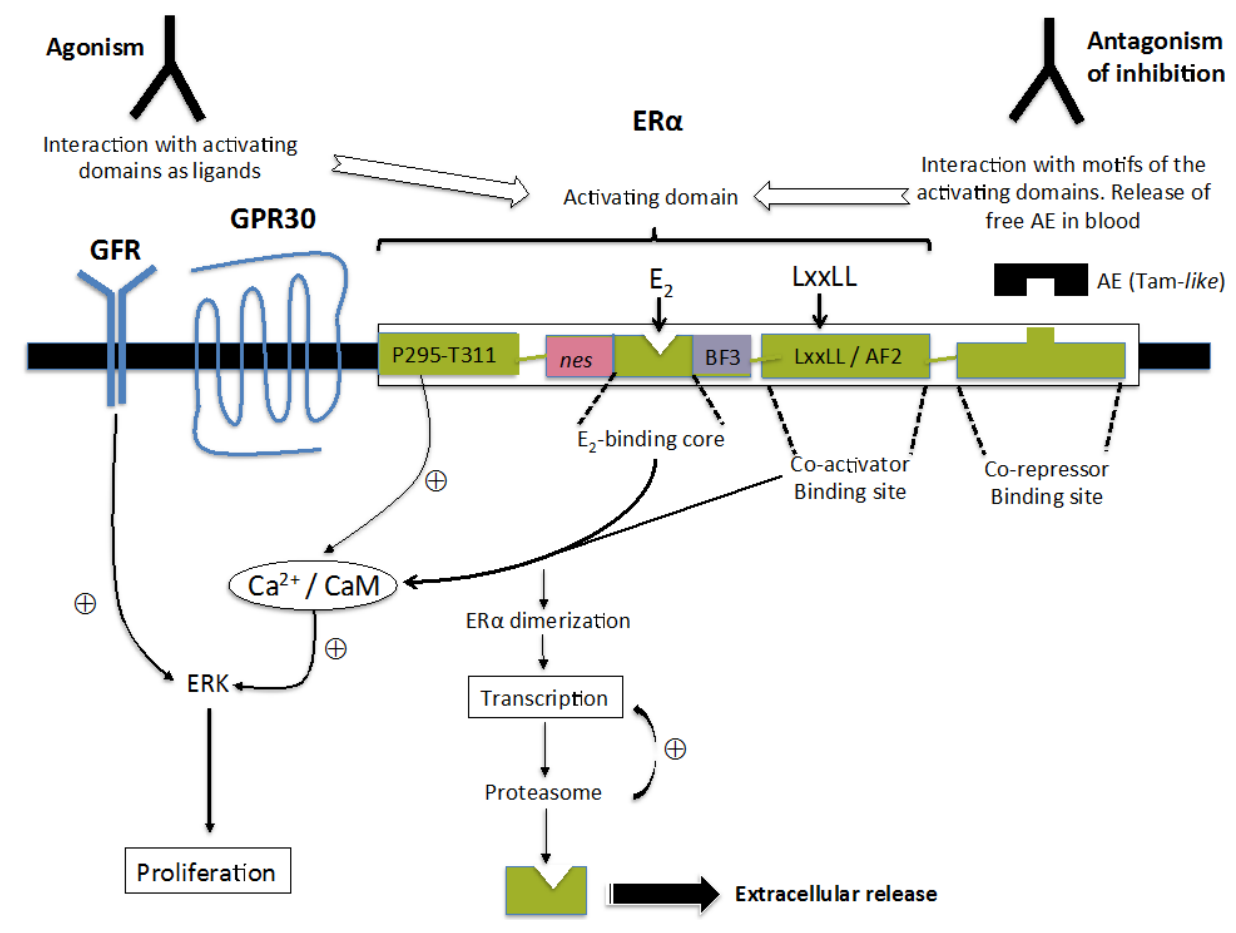

Figure 2. Schematic representation of $E R \alpha A B s-i n d u c e d$ mechanisms initiated at the plasma membrane to promote enhanced proliferation and ERE-dependent transcription. Reported ER $\alpha \mathrm{AB}$ activities (agonism, antagonism of inhibition) were integrated in a classical model explaining co-operation between binding sites for growth factors and steroid hormones in the onset of non-genomic and genomic responses $[11,12,14,27,33,37,38]$. Note the pivotal role of the $\mathrm{Ca}^{2+} /$ calmodulin complex in the inter-relationships between GPR30 and recruitment sites of the receptor for ER $\alpha$ ABs and adjacent co-activators. AE: antiestrogen; Tam-like: Tamoxifen-like.

\section{Mechanisms Implicated in the Emergence of ER $\alpha \mathrm{ABs}$}

The present section will solely refer to the emergence of $\mathrm{ER} \alpha \mathrm{ABs}$ for which $\mathrm{ER} \alpha$ binding properties have been overviewed. For any topics concerning $E_{2}$-related changes in immune functions or auto-immunity, I invite the reader to consult $[1,6]$, which are extensive in this regard. 
For me, insufficient experimental data have been reported to propose mechanisms giving rise to the production of ER $\alpha$ ABs. A priori, two auto-immune reactions involving eventually a contribution of the idiotypic network may theoretically be advocated, as suggested in the previous sections: one giving rise to antibodies acting as endogenous estrogenic secretions or any expositions to environmental estrogens, the other to antibodies abrogating the repressive action of a natural antagonist. In this context, one may wonder about the participation of recently identified circulating $\operatorname{ER}(\alpha$ and $\beta)$ forms in human sera in the emergence of ERABs (see Section 5.3). The next sections will analyze the relevance of these possibilities, schematically presented in Figure 3.

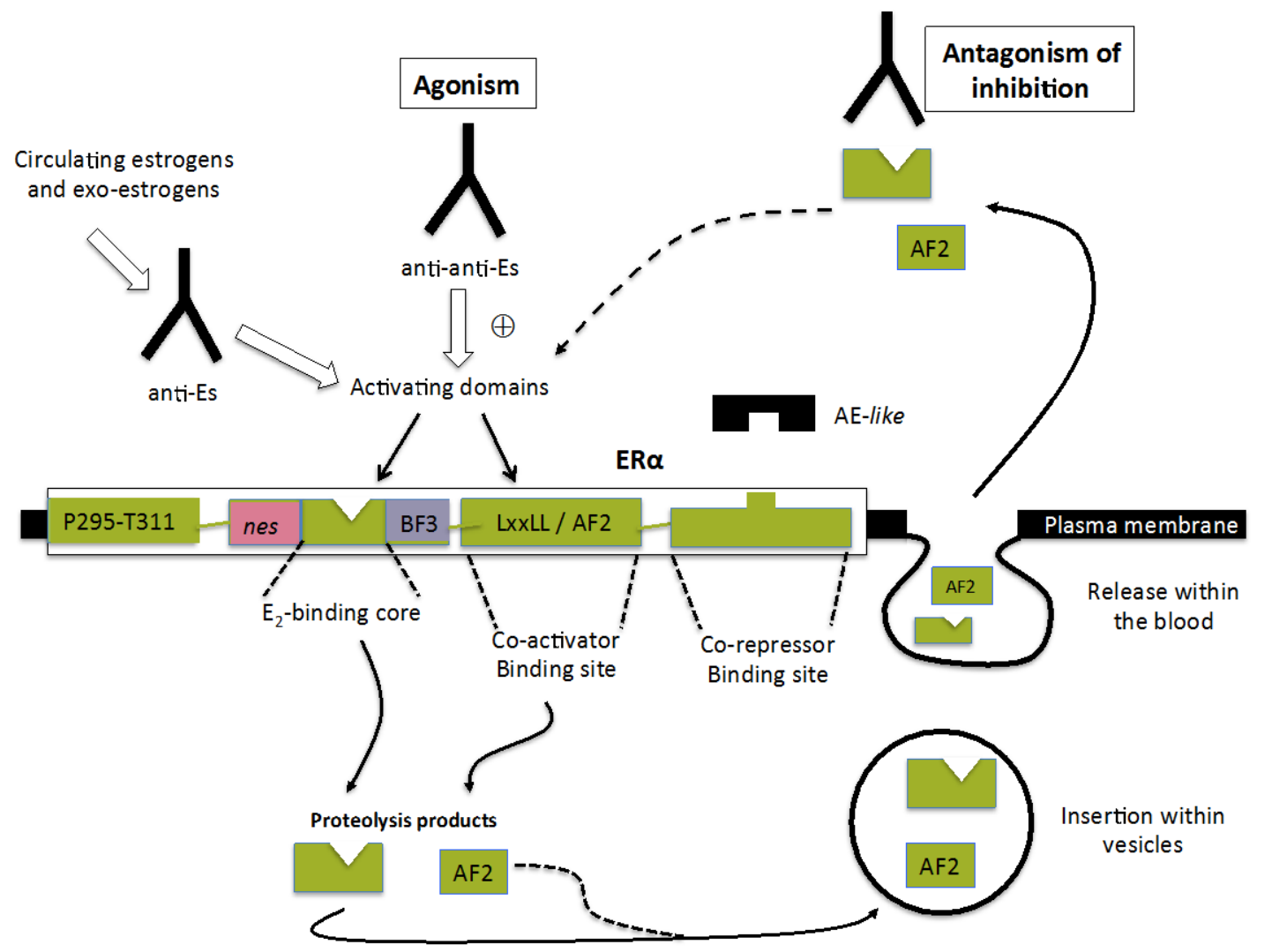

Figure 3. Schematic representation of suspected mechanisms able to contribute to ER $\alpha \mathrm{ABs}$ ' emergence. Agonists: antibodies able to mimic the action of circulating estrogens (natural, synthetic and xenoestrogens). Anti-antagonists: antibodies against a natural extra-cellular repressor recognizing a specific inhibitory site of ER $\alpha$ or preventing the access of activating modulators to the receptor by a competitive binding process. ER $\alpha$ degradation products including binding sites for estrogens or LXXLL motifs of co-activators [24], released within the blood, may generate this last class of antibodies. Es: Estrogens, BF3: Binding function 3, AF2: Activation function 2.

\subsection{Anti-Idiotypic Antibodies Acting as Physiological Estrogens}

Similarities between $\mathrm{E}_{2}$ and $\mathrm{ER} \alpha \mathrm{ABs}$, in terms of interactions with the native $\mathrm{ER} \alpha$ form, reflect most probably structural identities between the hormone and the active site of natural anti-idiotypic antibodies raised against anti- $E_{2}$ IgGs. Since circulating $E_{2}$ is mainly conjugated to serum proteins, one may postulate that such a cross-reaction may also hold for such conjugates, especially anti- $\mathrm{E}_{2} \sim \mathrm{BSA}$ IgGs, the level of which would largely dominate. Since such a concept is not restrictive to this hormone, it should be extended to all other physiological estrogens, as well as so-called "xenoestrogens" (natural phytoestrogens and synthetic "endocrine disrupting chemicals" [22,23]) able to interact with the ligand-binding site of ER $\alpha$ to induce estrogenic (or estrogenic-like) responses. The implication of these molecules in autoimmune response has been, indeed, evoked [47]. 
The production in the early 1990s of a monoclonal antibody (clone 1D5) directed against the binding site of an anti- $E_{2}$ monoclonal antibody lends credence to this concept: 1D5 was found to interact with the hormone-binding domain of the receptor to mimic some estrogenic actions (creatine kinase induction, rapid $\mathrm{Ca}^{2+}$ flux enhancement), both in vivo and in vitro [48,49]. These experimental data were proposed to be mainly dependent on an interaction with a membrane-bound form of ER $\alpha$. Nevertheless, they were also postulated to result to some extent from an intra-cellular penetration of 1D5. A lack of knowledge concerning the relationships between the plasma membrane and intra-cellular ER $\alpha$ forms at the time of such studies may explain this statement, which may appear now quite obsolete, even if this could not be excluded.

\subsection{Antibodies with Anti-Repressive Activities}

In theory, all receptor-mediated agonistic activities may result from an ability to abrogate the antagonism of a modulator acting at the level of the ligand-binding site or an adjacent site implicated in the recruitment of co-repressors. Such a view has been proposed to explain, at least in part, the estrogenic activity of ER $\alpha \mathrm{ABs}$ (Section 4, last paragraph). While a potency to liberate the $\mathrm{E}_{2}$-binding site of the plasma-bound receptor from the antagonism of a specific inhibitor has been solely addressed [5], it seems that other sites of the hormone-binding domain involved in the recruitment of co-activators (LXXLL/AF2, BF3, etc. [24,50]) must also be taken into account. However, the presence of such sites in the whole family of steroid hormone receptors would largely limit the specificity of action of antibodies raised against them, giving rise to inappropriate adverse effects. Hence, their importance seems quite dubious.

In this context, a possible interaction of $\mathrm{ER} \alpha \mathrm{ABs}$ with an identified $\mathrm{ER} \alpha$-binding site implicated in the recruitment of tamoxifen and other mixed antagonists/agonists [51,52] may also be advocated. Experiments revealed that that treatment of cytosolic ER $\alpha$ preparations with tamoxifen enhances the immuno-reactivity of this site for a monoclonal antibody (H222) raised against an epitope of the receptor ligand-binding domain [53], revealing that this compound may expose an occult antigenic determinant accessible to a subpopulation of ER $\alpha$ ABs. Whatever could be the finality of such an interaction with a site contributing to the activity of tamoxifen, either agonist or antagonist, one may consider that it may modulate the SERM character of this compound.

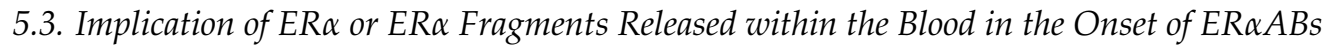

Could ER $\alpha$ and $\beta$ recently detected within human sera [54] be implicated in the emergence of $E R \alpha A B s$ against these two receptors? This important question has some justification in the finding that the latter display anti-inflammatory properties, the net action of which depends on their relative proportions $(\beta>\alpha)$ and localization; ER $\alpha$ is moreover associated with auto-immune processes [55].

These circulating ER $\alpha$ and $\beta$ forms (detected in patients with Crohn's disease with a commercial ELISA) most probably correspond to various receptor fragments issued from their intracellular proteasomal and lysosomal degradation, released within the blood as small vesicles (exosomes) implicated in immune responses or processed for MHC (major histocompatibility complex) presentation after autophagy [56,57]. Hence, one may logically assume that ER $\alpha$ fragments may be implicated in the emergence of ER $\alpha \mathrm{ABs}$ with a repressive activity, some of them abrogating the effect of natural inhibitors present in the blood, others abrogating the potent competitive inhibitory potency of $\mathrm{ER} \alpha$ degradation products able to recruit circulating activators (mainly $\mathrm{E}_{2}$, co-activators), liberating thereby these agents for the accomplishment of their function.

The detection in media from $\mathrm{E}_{2}$-stimulated cells of a 44-amino-acid peptide including a repressive motif of ER $\alpha$ (Pro295-Thr311) [58], able to interact with the Pro365-Asp369 type II $\beta$ turn element of its BF3 motif that regulates the dimerization of the receptor ([59], and see Section 6), may appear as a stone in the edification of this concept. A synthetic peptide corresponding to the Pro295-Thr311 motif $(E R \alpha 17 p)$ induces indeed estrogenic responses, as well as some receptor-independent actions in various breast cancer cell lines [60], the lack of specificity of these actions resulting most probably 
from distinct interactions with the type II $\beta$ turn/BF3 motifs of the various steroid hormone receptors expressed in these cells. Antibodies raised against the P295-T311 sequence (Gentaur: 04-rb-ER $\alpha 17 \mathrm{p}$ ) would logically generate a similar absence of specificity of action in contrast to antibodies raised against the E2-binding core of the receptor (Section 5.2, first paragraph). Such a lack of specificity would not be necessarily detrimental for therapeutic purposes, especially in the case of antiestrogen resistance, as proposed for antagonists aimed to antagonize the recruitment of co-activators [24,61].

\section{Conclusions and Perspectives}

Structural studies of the estrogenic core of $E R \alpha$, reported here, reveal that the ER $\alpha \mathrm{ABs}$ epitope localizes at a place of prominent importance for the successive onset of non-genomic and genomic responses. The finding that this epitope is adjacent to regulatory motifs governing these responses argues in favor of such a statement. Complementary inclusion of these data into a model established from X-ray crystallographic investigations relevant to the activated intracellular ER $\alpha$ form indicated that the Leu479-Thr485 motif, which contributes to the dimerization of the receptor, corresponds to a part of its BF3 motif implicated in ERE-dependent transcription [61] (Figure 4; analysis performed by my colleague Yves Jacquot, Sorbonne Universités, Université Pierre et Marie Curie, Ecole Normale Supérieure, Paris, France). This information strongly suggests that ligand-induced conformational changes relevant to the intracellular receptor may also hold for its plasma membrane-bound form, justifying the dimerization ability of the latter. Hence, the biochemical assessment of the interactions between ligands aimed at targeting the "insoluble" ER $\alpha$ entrapped within the plasma membrane and the conventional "soluble" cytoplasmic and nuclear receptor forms would be a valuable approach to the decryption of the mechanism by which ER $\alpha$ operates. Hence, interest in ER $\alpha$ ABs would not be restricted to physio/pathological purposes.

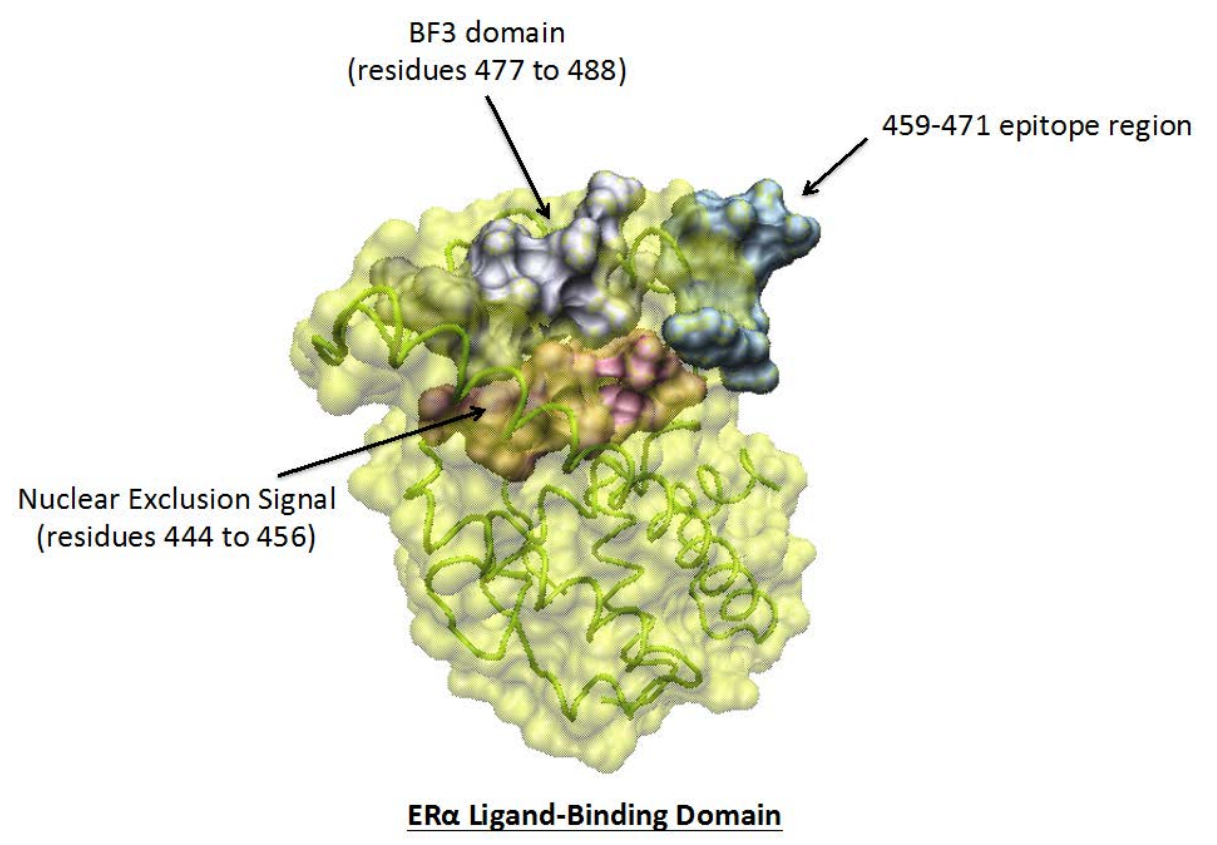

Figure 4. Surface structure of the BF3- (in grey) and $\mathrm{ER} \alpha \mathrm{AB}$ epitope/ $\mathrm{E}_{2}$ (in blue)-binding domains of the human estrogen receptor $\alpha$ (ER $\alpha$ in yellow, Connolly surface). The BF3 domain is composed of two regions, i.e., the 365-369 type II $\beta$-turn region and the $477-488$ helix 10 (H10) region, the latter overlapping the $479-485$ sequence implicated in the dimerization of the receptor. The ER $\alpha$ ABs epitope is in close contact with this BF3 domain, as well as the $444-456$ nuclear exclusion site (nes, for nuclear exclusion signal, in pink). Interaction between the 301-311 region with the 365-269 type II $\beta$ turn seems to repress the dimerization potency of the 477-488 helix. Transparency allows the visualization of the helices (in green) that comprise the receptor. 
In this regard, experimental data critically reviewed here leave no doubt about the importance of $E R \alpha A B s$ in breast cancer emergence and/or evolution, even if these biological aspects have only been marginally addressed at the present time [2,5]. The capacity of ER $\alpha$ ABs to stimulate MCF-7 cell growth suggests some potential implication in the resistance to endocrine treatments. Such a topic needs to be rapidly assessed with tamoxifen-resistant cell lines. On the other hand, since the mammary gland is under the control of both ER $\alpha$ and $\beta$, which respectively promote or repress its neoplasia [62], the search for natural antibodies raised against ER $\beta$ seems of major interest. Such a task may open new pathways in the current tendency to combine immunological and endocrine approaches in the management of cancer. The present review being mainly devoted to fundamental aspects of ER $\alpha \mathrm{ABs}$, I encourage immunologists and endocrinologists to extend my work to reported clinical observations, especially those that, by ignorance, I failed to refer. Such an issue will be extremely helpful to confirm or reject a tendency to see a strong autoimmune ER function in breast cancer, which, in the affirmative, would be taken into account in the design of future therapeutic programs.

Acknowledgments: I warmly thank Yves Jacquot (Sorbonne Universités, Université Pierre et Marie Curie, Ecole Normale Supérieure, Paris, France), my friend, for his help in the design of the figures. Our long-term cooperation in the investigation of the processes by which ER $\alpha$ operates must be stressed. In the present context, this obviously contributes to the concepts that I propose.

Conflicts of Interest: The author declares no conflict of interest. As Honorary (retired) Professor, I failed to have access to any kind of financial support.

\section{Abbreviations}

$\begin{array}{ll}\text { Akt } & \text { Protein kinase B } \\ \text { AF2 } & \text { Activation function 2 } \\ \text { BF3 } & \text { Binding function 3 } \\ \text { ERK } & \text { Extracellular regulated kinase } \\ \text { EGFR } & \text { Epidermal growth factor receptor } \\ \text { ER } & \text { Estrogen receptor } \\ \text { ERAB } & \text { Estrogen receptor antibody } \\ \text { ERE } & \text { Estrogen response element } \\ \text { HER 2 } & \text { Human epidermal growth factor 2 } \\ \text { IP3 } & \text { Inositol triphosphate }\end{array}$

\section{References}

1. Ortona, E.; Pierdominici, M.; Berstein, L. Autoantibodies to estrogen receptors and their involvement in autoimmune diseases and cancer. J. Steroids Biochem. Biophys. Mol. Biol. 2014, 144, 260-267. [CrossRef] [PubMed]

2. Maselli, A.; Capoccia, S.; Pugliese, P.; Raggi, C.; Cirulli, F.; Fabi, A.; Maloni, W.; Pierdominici, M.; Ortona, E. Autoantibodies specific to estrogen receptor alpha act as estrogen agonists and their levels correlate with breast cancer cell proliferation. Oncoimmunology 2016, 5, e1074375. [CrossRef] [PubMed]

3. Borkowski, A.; Gyling, M.; Muquardt, C.; Body, J.J.; Leclercq, G. A subpopulation of immunoglobin G in man selectively interacts with the hormone-binding sites of estrogen receptors. J. Clin. Endocrinol. Metab. 1987, 64, 356-363. [CrossRef] [PubMed]

4. Borkowski, A.; Gyling, M.; Muquardt, C.; Body, J.J.; Leclercq, G. Estrogen-like activity of a subpopulation of natural antiestrogen receptor autoantibodies in man. Endocrinology 1991, 128, 3283-3292. [CrossRef] [PubMed]

5. Tassignon, J.; Haeseleer, F.; Borkowski, A. Natural antiestrogen receptor autoantibodies in man with estrogenic activity in mammary carcinoma cell culture: Study of their mechanism of action; evidence for involvement of estrogen-like epitopes. J. Clin. Endocrinol. Metab. 1997, 82, 3464-3470. [CrossRef] [PubMed]

6. Ortona, E.; Pierdominici, M.; Maselli, A.; Veronesi, C.; Aloisi, F.; Shoenfeld, Y. Sex-based differences in autoimmune diseases. Annali Dell'Istituto Superiore Di Sanita 2016, 52, 205-212. [CrossRef] [PubMed] 
7. Weigel, N.L.; Pousette, A.; Schrader, W.T.; O'Malley, B.W. Analysis of chicken progesterone receptor structure using a spontaneous sheep antibody. Biochemistry 1981, 20, 6798-6802. [CrossRef] [PubMed]

8. Liao, S.; Witte, D. Auto immune anti-androgen-receptor antibodies in human serum. Proc. Natl. Acad. Sci. USA 1985, 82, 8345-8348. [CrossRef] [PubMed]

9. Muddaris, A.; Peck, E.J., Jr. Human anti-estrogen receptor antibodies: Assay, characterization and age- and sex-related differences. J. Clin. Endocrinol. Metab. 1987, 64, 246-254. [CrossRef] [PubMed]

10. Hammes, S.R.; Levin, E.R. Extranuclear steroid receptors: Nature and actions. Endocr. Rev. 2007, $28,726-741$. [CrossRef] [PubMed]

11. Schwartz, N.; Verma, A.; Bivens, C.B.; Schwartz, Z.; Boyan, B.D. Rapid steroid hormone actions via membrane receptors. Biochem. Biophys. Acta 2016, 1863, 2289-2298. [CrossRef] [PubMed]

12. Leclercq, G.; Lacroix, M.; Laios, J.; Laurent, G. Estrogen receptor alpha: Impact of ligands on intracellular shuttling and turnover rate in breast cancer cells. Curr. Cancer Drug Targets 2006, 6, 39-64. [CrossRef] [PubMed]

13. La Rosa, P.; Perisi, V.; Leclercq, G.; Marino, M.; Acconcia, F. Palmitoylation regulates $17 \beta$-estradiol-induced estrogen receptor- $\alpha$ degradation and transcriptional activity. Mol. Endocrinol. 2012, 26, 762-764. [CrossRef] [PubMed]

14. Tecalco-Cruz, A.C.; Pérez-Alvarado, I.A.; Ramirez-Jarquin, J.O. Nucleo-cytoplasmic transport of estrogen receptor alpha in breast cancer cells. Cell. Signal. 2017, 34, 121-132. [CrossRef] [PubMed]

15. Laïos, I.; Journe, F.; Laurent, G.; Nonclercq, D.; Toillon, R.A.; Seo, H.S.; Leclercq, G. Mechanisms governing the accumulation of estrogen receptor alpha in MCF7 cells treated with hydroxytamoxifen and reated antiestrogens. J. Steroid Biochem. Mol. Biol. 2003, 87, 207-211. [CrossRef] [PubMed]

16. Jensen, E.V.; Block, G.E.; Smith, S.; Kyser, K.; De Sombre, E.R. Estrogen receptors and breast cancer response to adrenalectomy. Prediction of response in cancer therapy. NCI Monogr. 1971, 34, 55-70.

17. Leclercq, G.; Heuson, J.C. Specific estrogen receptor of the DMBA-induced mammary tumor of the rat and its requiring molecular transformation. Eur. J. Cancer 1973, 9, 675-680. [CrossRef]

18. Seielstad, D.A.; Carson, K.; Kushner, P.J.; Greene, G.L.; Katzenellengogen, J.A. Analysis of the structural core of the human estrogen ligand binding domain by selective proteolysis/mass spectrometry analysis. Biochemistry 1995, 34, 12605-12615. [CrossRef] [PubMed]

19. Thole, H.H.; Jungblut, P.W. The ligand-binding site of the estradiol receptor resides in a non-covalent complex of two consecutive peptides of 17 and 7 kDa. Biochem. Biophys. Res. Commun. 1994, 199, 826-833. [CrossRef] [PubMed]

20. Anstead, G.M.; Carlson, K.E.; Katzenellenbogen, J.A. The estradiol pharmacophore: Ligand-estrogen-receptor binding affinity relationship and a model for the receptor binding site. Steroids 1997, 62, 268-303. [CrossRef]

21. Fink, B.E.; Mortensen, D.S.; Staufer, S.R.; Aron, Z.; Katzenellenbogen, J.A. Novel structural templates for estrogen-receptor ligands and prospects for combinatorial synthesis of estrogens. Chem. Biol. 1999, 6, 205-219. [CrossRef]

22. Jacquot, Y.; Rojas, C.; Refouvelet, B.; Robert, J.F.; Leclercq, G.; Xicluna, A. Recent advances in the development of phytoestrogens and derivatives: An update of the promising perspectives in the prevention of postmenopausal diseases. Mini-Rev. Med. Chem. 2003, 2, 387-400. [CrossRef]

23. Lóránd, T.; Vigh, E.; Garai, J. Hormonal action of plant derived and antropogenic non-steroidal estrogenic compounds; phytoestrogens and xenoestrogens. Curr. Med. Chem. 2010, 17, 3542-3574. [CrossRef] [PubMed]

24. Leclercq, G.; Gallo, D.; Cossy, J.; Laïos, I.; Larsimont, D.; Laurent, G.; Jacquot, Y. Peptides targeting estrogen receptor alpha-potential applications for breast cancer treatment. Curr. Pharm. Des. 2011, 17, 2632-2653. [CrossRef] [PubMed]

25. Lombardi, M.; Castoria, G.; Migliaccio, A.; Barone, M.V.; Di Stasio, R.; Ciociola, A.; Bottero, D.; Yagamuchi, H.; Appela, E.; Auricchio, F. Hormone-dependent nuclear export of estradiol receptor and DNA synthesis in breast cancer cells. J. Cell Biol. 2008, 182, 327-340. [CrossRef] [PubMed]

26. Nonclercq, D.; Journe, F.; Laïos, I.; Chaboteaux, C.; Toillon, R.A.; Leclercq, G.; Laurent, G. Effect of nuclear export inhibition on estrogen receptor regulation in breast cancer cells. Mol. Endocrinol. 2007, 39, 105-118. [CrossRef] [PubMed]

27. Tecalco-Cruz, A.C. Molecular pathways involved in the transport of nuclear receptors from the nucleus to the cytoplasm. J. Steroid Biochem. Mol. Biol. 2018, in press. [CrossRef] [PubMed] 
28. Acconcia, F.; Ascenzi, P.; Fabozzi, G.; Visca, P.; Marino, M. S-palmitoylation modulates human estrogen receptor-alpha functions. Biochem. Biophys. Res. Commun. 2004, 316, 878-883. [CrossRef] [PubMed]

29. Chalkaraborty, S.; Biswas, B.K.; Asare, B.K.; Rajnarayanan, R.V. Designer interface peptide grafts target estrogen receptor alpha dimerization. Biochem. Biophys. Res. Commun. 2016, 47, 116-122. [CrossRef] [PubMed]

30. Mizwicki, M.T.; Keidel, D.; Bula, C.M.; Bishop, C.M.; Zanello, L.; Wurtz, J.M.; Moras, D.; Norman, A.W. Identification of an alternative ligand-binding pocket in the nuclear vitamine $\mathrm{D}$ receptor and its functional importance in $1 \alpha, 25(\mathrm{OH})_{2}$-vitamin $\mathrm{D}_{3}$ signaling. Proc. Natl. Acad. Sci. USA 2004, 101, 12876-12881. [CrossRef] [PubMed]

31. Norman, A.W.; Mizwicki, M.T.; Norman, D.P. Steroid-hormone rapid actions. Membrane receptors and conformational ensemble model. Nat. Rev. Drug Discov. 2004, 3, 27-41. [CrossRef] [PubMed]

32. Van Hoorn, W.P. Identification of a second binding site in estrogen receptor. J. Med. Chem. 2002, 45, 584-589. [CrossRef] [PubMed]

33. Bennesch, M.A.; Picard, D. Minireview. Tipping the balance: Ligand-independent activation of steroids receptors. Mol. Endocrinol. 2015, 29, 349-363. [CrossRef] [PubMed]

34. Shearer, K.E.; Rickter, E.L.; Peterson, A.C.; Weatherman, R.V. Dissecting rapid estrogen signaling with conjugates. Steroids 2012, 77, 968-973. [CrossRef] [PubMed]

35. Zhang, X.; Wang, Z.Y. Estrogen receptor- $\alpha$ variant, ER- $\alpha 36$, is involved in tamoxifen resistance and estrogen hypersensitivity. Endocrinology 2013, 154, 1990-1998. [CrossRef] [PubMed]

36. Lin, A.H.; Li, R.W.; Ho, E.Y.; Leung, S.W.; VanHoute, P.M.; Man, R.Y. Differential ligand binding affinities of human estrogen receptor- $\alpha$ isoforms. PLoS ONE 2013, 8, e63199. [CrossRef] [PubMed]

37. Prossnitz, E.R.; Maggliolini, M. Mechanism of estrogen signaling and gene expression via GPR30. Mol. Cell. Endocrinol. 2009, 308, 32-38. [CrossRef] [PubMed]

38. Levin, E.R. G protein-coupled receptor 30: Estrogen receptor or collaborator? Endocrinology 2009, 150, 1563-1565. [CrossRef] [PubMed]

39. Notas, G.; Kampa, M.; Pelekanou, V.; Castanas, E. Interplay of estrogen receptors and GPR30 for the regulation of early initiated transcriptional effects: Pharmacological approach. Steroids 2012, 77, 943-950. [CrossRef] [PubMed]

40. Tran, Q.K.; Vermeer, M. Biosensor-based approach identifies four distinct calmodulin-binding domains in the G-coupled estrogen receptor 1. PLoS ONE 2014, 9, e89669. [CrossRef] [PubMed]

41. Leiber, D.; Burlina, F.; Byrne, C.; Robin, P.; Piesse, C.; Gonzalez, L.; Leclercq, G.; Tanfin, Z.; Jacquot, Y. The sequence Pro ${ }^{295}$-Ther ${ }^{311}$ of the hinge of oestrogen receptor $\alpha$ is involved in ERK1/2 activation via GPR30 in leiomyoma cells. Biochem. J. 2015, 472, 97-109. [CrossRef] [PubMed]

42. Gallo, D.; Jacquot, Y.; Laurent, G.; Leclercq, G. Calmodulin, a regulatory partner of the estrogen receptor alpha in breast cancer cells. Mol. Cell. Endocrinol. 2008, 268, 20-26. [CrossRef] [PubMed]

43. Li, Z.; Zhang, Y.; Hedman, A.C.; Ames, J.B.; Sacks, D.B. Calmodulin lobes facilitate dimerization and activation of estrogen receptor- $\alpha$. J. Biol. Chem. 2017, 292, 4614-4622. [CrossRef] [PubMed]

44. Cheng, S.B.; Graeber, C.T.; Quin, J.A.; Filardo, E.J. Retrograde transport of the transmembrane estrogen receptor, G-protein-coupled-receptor-30 (GPR30/GPER) from the plasma membrane towards thenucleus. Steroids 2011, 76, 892-896. [CrossRef] [PubMed]

45. Vu, T.; Claret, F.X. Trastuzumab: Updated mechanisms of action and resistance in breast cancer. Front. Oncol. 2012, 2, 62. [CrossRef] [PubMed]

46. Harbeck, N.; Beckmann, M.W.; Rody, A.; Schneeweiss, A.; Müller, V.; Fehm, T.; Marschner, N.; Gluz, O.; Schader, I.; Heinrich, G.; et al. HER2 dimerization inhibitor pertuzumab-Mode of action and clinical data in brest cancer. Brest Cancer 2013, 8, 49-55. [CrossRef]

47. Chighizola, C.; Meroni, P.L. The role of environmental estrogens and autoimmunity. Autoimmun. Rev. 2012, 11, A493-A501. [CrossRef] [PubMed]

48. Mor, G.; Amir-Zaltsman, Y.; Barnard, G.; Kohen, F. Characterization of an antiidiotypic antibody mimicking the actions of estradiol and its interaction with estrogen receptors. Endocrinology 1992, 130, 3633-3640. [CrossRef] [PubMed]

49. Sömjen, D.; Kohen, F.; Lieberherr, M. Nongenomic effects of an anti-idiotypic antibody as an estrogen mimetic in female human and rat osteoblasts. J. Cell. Biochem. 2007, 65, 53-66. [CrossRef] 
50. Buzón, V.; Carbo, L.R.; Estruch, S.B.; Fletterick, R.J.; Estébanez-Perpina, E. A conserved surface on the ligand binding domain of nuclear receptors for allosteric control. Mol. Cell. Endocrinol. 2012, 348, $394-402$. [CrossRef] [PubMed]

51. Berthois, Y.; Pons, M.; Dussert, C.; Crastes de Paulet, A.; Martin, P.M. Agonist-antagonist activity of anti-estrogens in the human breast cancer cell line MCF-7: An hypothesis for the interaction with a site distinct from the estrogen binding site. Mol. Cell. Endocrinol. 1994, 99, 259-268. [CrossRef]

52. Kojetin, D.J.; Burris, T.P.; Jensen, E.V.; Khan, S.A. Implications of the binding of tamoxifen to the coactivator recognition site of the estrogen receptor. Endocr. Relat. Cancer 2008, 15, 851-870. [CrossRef] [PubMed]

53. Martin, P.M.; Berthois, Y.; Jensen, E.V. Binding of antiestrogens exposes an occult antigenic determinant in the human estrogen receptor. Proc. Natl. Acad. Sci. USA 1988, 85, 2533-2537. [CrossRef] [PubMed]

54. Linares, P.M.; Algaba, A.; Urzainqui, A.; Guijarro-Rojas, M.; Gonzalez-Tajuelo, R.; Garrido, J.; Chaparro, M.; Gisbert, J.P.; Bermejo, F.; Guerra, I.; et al. Ratio of circulating estrogen receptors beta and alpha (ER $\beta / E R \alpha)$ indicates endoscopic activity in patients with Crohn's disease. Dig. Dis. Sci. 2017, 62, 2744-2754. [CrossRef] [PubMed]

55. Hill, L.; Jeganathan, V.; Chinnasamy, P.; Grimaldi, C.; Diamond, B. Differential roles of estrogen receptors $\alpha$ and $\beta$ in control of B-cell maturation and selection. Mol. Med. 2011, 17, 211-220. [CrossRef] [PubMed]

56. Beninson, L.A.; Fleshner, M. Exosomes: An emerging factor in stress-induced immunomodulation. Semin. Immunol. 2014, 26, 394-401. [CrossRef] [PubMed]

57. Schmid, D.; Münz, C. Innate and adaptive immunity through autophagy. Immunity 2007, 27, 11-21. [CrossRef] [PubMed]

58. Gallo, D.; Leclercq, G.; Haddad, J.; Vinh, J.; Castanas, E.; Kampa, M.; Pelekanou, V.; Jacquot, Y. Estrogen Receptor Alpha Polypeptide Sequence, Diagnostic and Therapeutic Applications Thereof. U.S. Patent WO 20120449229 A1, 19 April 2012.

59. Jacquot, Y.; Gallo, D.; Leclercq, Y. Estrogen receptor alpha-Identification by a modelling approach of a potential polyproline II recognizing domain within the AF-2 region of the receptor that would play a role of prime importance in its mechanism of action. J. Steroid. Biochem. Mol. Biol. 2007, 104, 1-10. [CrossRef] [PubMed]

60. Notas, G.; Kampa, M.; Pelekanou, V.; Troullinki, M.; Jacquot, Y.; Leclercq, G.; Castanas, E. Whole transcriptome analysis of the ER $\alpha$ synthetic fragment P295-T311 (ER $\alpha 17 p)$ identifies specific ER $\alpha$ isoform $(\mathrm{ER} \alpha, \mathrm{ER} \alpha 36)-d e p e n d e n t$ and-independent actions in breast cancer cells. Mol. Oncol. 2013, 7, 595-610. [CrossRef] [PubMed]

61. Gallo, D.; Leclercq, G.; Jacquot, Y. The N-terminal part of the ligand-binding domain of the human estrogen receptor $\alpha$ : A new target for estrogen disruptors. In Medicinal Chemistry Research Progress; Colombo, G.P., Ricci, S., Eds.; Nova: Hauppauge, NY, USA, 2009; pp. 207-224.

62. Treeck, O.; Lattrich, C.; Springwald, A.; Ortmann, O. Estrogen receptor beta exerts growth-inhibitory effects on human mammary epithelial cells. Breast Cancer Res. Treat. 2010, 557-565. [CrossRef] [PubMed] 